\title{
Manajemen Pembenihan Udang Vaname Litopenaeus vannamei di PT Central Proteina Prima, Kalianda, Lampung Selatan
}

\section{Management of White Shrimp Litopenaeus vannamei Hatchery at PT Central Proteina Prima, Kalianda, South Lampung}

\author{
Andri Iskandar*1, Afrizal Rizki ${ }^{1}$, Andri Hendriana1 ${ }^{1}$, Giri Maruto Darmawangsa1, ${ }^{1}$ Abuzzar $^{2}$, \\ Khoerullah $^{2}$, dan Muksin ${ }^{2}$ \\ ${ }^{1}$ Program Studi Teknologi Produksi dan Manajemen Perikanan Budidaya, Sekolah Vokasi, \\ Institut Pertanian Bogor, Bogor \\ ${ }^{2}$ PT Central Proteina Prima, Kalianda, Lampung Selatan, Lampung \\ *E-mail: andriiskandar@apps.ipb.ac.id
}

\begin{abstract}
ABSTRAK
Udang vaname Litopeneaus vannamei merupakan komoditas ekspor unggulan Indonesia dengan permintaan pasar yang cukup tinggi dan memiliki prospek pasar yang berkembang pesat. Kegiatan pembenihan meliputi persiapan wadah, pemeliharaan induk, pemijahan induk, pengeluaran telur, penetasan telur, pemeliharaan naupli, pemeliharaan larva/benur, kultur pakan alami, pengelolaan kualitas air, pencegahan hama dan penyakit, serta pemanenan larva/benur. Produktivitas dari satu induk udang vaname sebanyak 300.000 telur dengan FR $86 \%$ dan HR $85 \%$. Produksi dari kegiatan pembenihan dapat mencapai 2.607.428.880 ekor tahun ${ }^{-1}$ yang terdiri dari 360 siklus. Produksi yang dihasilkan dari kegiatan pembenihan yaitu post larva 4 dan 7 dengan SR $75 \%$.

Kata kunci: udang vaname, pembenihan, produksi.
\end{abstract}

\section{PENDAHULUAN}

Indonesia merupakan negara kepulauan terbesar di dunia dengan luas wilayah laut yang dapat dikelola sebesar 5,8 juta $\mathrm{km}^{2}$ yang memiliki keanekaragaman sumber daya kelautan dan perikanan yang sangat besar. Potensi untuk perikanan budidaya air laut seluas 8,3 juta ha yang terdiri dari $20 \%$ untuk budidaya ikan, $10 \%$ untuk budidaya kekerangan, $60 \%$ untuk budidaya rumput laut, $10 \%$ untuk lainnya, dan perikanan budidaya air payau atau tambak memiliki luas 1,3 juta ha (KKP 2011). Berdasarkan data Food Agriculture Organization (FAO) (2014), pada tahun 2012 Indonesia menempati peringkat ke-4 untuk produksi perikanan budidaya dengan jumlah produksi budidaya laut (Mariculture) sebesar 582.077 Ton dan sebagian besar diantaranya adalah komoditas crustaceans yaitu sebesar 387.698 Ton.

Terdapat dua jenis udang unggulan ekspor Indonesia. Pertama, spesies udang vaname Litopenaeus vannamei, kedua, spesies udang windu Paneus monodon. Udang vaname adalah salah satu jenis udang yang habitat aslinya di pantai dan laut Amerika Latin, seperti Mexico dan Puertorico. Udang windu merupakan udang asli Indonesia yang harus tetap dikembangkan, tetapi dilihat dari segi produksi udang windu kalah saing dengan udang vaname. Udang vaname adalah salah satu spesies udang yang bernilai ekonomis dan merupakan salah satu komoditas unggulan nasional

PT Central Proteina Prima (CPP) Kalianda adalah sebuah perusahaan swasta yang bergerak pada bidang perikanan dalam penyediaan benih udang vaname. Proses pembenihan dilakukan menggunakan induk udang yang sudah memiliki standar Specific Pathogen Free (SPF) serta telah melalui tahapantahapan seleksi induk sesuai biosecurity, sehingga mampu menghasilkan benih yang berkualitas. 


\section{METODE}

Kegiatan pembenihan udang vaname dilaksanakan pada tanggal 6 Januari-19 Februari 2020 di PT CPP Kalianda, Lampung Selatan. Metode yang dilakukan dalam kegiatan ini adalah mengikuti dan melakukan secara langsung seluruh kegiatan, melakukan pengamatan serta observasi, melakukan wawancara dengan pihak-pihak yang berkompeten di bidangnya, melakukan pencatatan dan mengumpulkan informasi-informasi serta studi pustaka materi terkait.

\section{HASIL DAN PEMBAHASAN}

Persiapan Wadah Pemeliharaan Induk. Kegiatan pembenihan udang vaname meliputi persiapan wadah, pemeliharaan induk, pemijahan induk, pengeluaran telur, penetasan telur, pemeliharaan naupli, pemeliharaan larva/benur, kultur pakan alami, pengelolaan kualitas air, pencegahan hama dan penyakit, serta pemanenan larva/benur.

Induk didatangkan langsung dari Shrimp Improvement System (SIS) Hawaii dan Florida. Induk bersertifikasi Spesific Pathogen Free (SPF) dan merupakan keturunan F1. Pada saat awal kedatangan, induk dipelihara di dalam wadah karantina selama 14 hari. Wadah karantina terbuat dari bak beton berukuran $8 \mathrm{~m}$ x $4 \mathrm{~m}$ x $1 \mathrm{~m}$. Persiapan wadah karantina dilakukan 3 hari sebelum kedatangan induk. Persiapan wadah yang dilakukan yaitu pencucian dengan detergen $10 \mathrm{~g} \mathrm{~L}^{-1}$ yang kemudian dibilas dengan air laut, lalu pasang instalasi aerasi, dan dilakukan penyiraman dengan larutan povidone iodine $400 \mu \mathrm{L} \mathrm{L}^{-1}$. Povidone iodine memiliki spektrum yang luas dari aktivitas antimikroba terhadap bakteri, jamur, protozoa, dan virus, serta dapat digunakan untuk mengobati luka akut dan kronis (Sibbald et al. 2011). Wadah selanjutnya diisi air dengan volume air 12,8 Ton atau ketinggian air $40 \mathrm{~cm}$.

Persiapan Wadah Pemijahan, Penetasan Telur dan Penampungan Naupli. Persiapan wadah dilakukan dengan cara penyiraman kaporit $\mathrm{Ca}(\mathrm{ClO})_{2} 500 \mathrm{mg} \mathrm{L}^{-1}$ yang kemudian wadah dicuci menggunakan detergen $10 \mathrm{~g} \mathrm{~L}^{-1}$, setelah itu dibilas dengan air bersih, lalu dilakukan pengeringan selama 24 jam. Dilakukan pemasangan aerasi dan pengisian air laut setelah proses pengeringan.

Penebaran Induk. Kedatangan induk ke Central Naupli Production Departement (CNPD) menggunakan mobil truk. Tahapan sebelum induk ditebar diantaranya pemisahan boks kemasan yang berisi induk jantan dan betina. Pemeriksaan surat-surat verifikasi kedatangan induk (invoice) seperti informasi jumlah, asal, suhu, dan salinitas. Pemeriksaan kualitas air kantong kemasan dan bak yang akan digunakan ( $\mathrm{pH}$, suhu, DO, dan salinitas), pengambilan sample dari setiap induk jantan dan betina untuk diperiksa menggunakan metode PCR dan mikrobiologi, serta untuk monitoring oleh pihak karantina. Transfer kantong pengemasan induk ke bak karantina melewati proses dipping dengan povidone iodine $1.000 \mu \mathrm{L} \mathrm{L}^{-1}$, lalu dilakukan proses aklimatisasi suhu dan $\mathrm{pH}$ selama 30-35 menit atau setelah mendekati selisih suhu dan $\mathrm{pH}$ yang ditentukan. Penambahan larutan asam cuka $\left(\mathrm{CH}_{3} \mathrm{COOH}\right)$ ke dalam kantong saat proses aklimatisasi yang bertujuan agar $\mathrm{pH}$ air wadah sama dengan $\mathrm{pH}$ air dalam kantong pengemasan induk. Kantong kemas akan dibuka setelah perbedaan suhu maksimal $2{ }^{\circ} \mathrm{C}$ dan $\mathrm{pH}$ air maksimal 0,5 . Untuk mencegah penyebaran hama penyakit, air bekas pengangkutan di dalam kantong kemas dan air limbah dari wadah budidaya dilakukan dossing dengan kaporit $8 \mu \mathrm{L} \mathrm{L}^{-1}$. Padat penebaran induk di bak karantina yaitu 10 ekor $\mathrm{m}^{-2}$ dan padat tebar induk di bak maturasi yaitu 9 ekor $\mathrm{m}^{-2}$.

Manajemen Pakan Induk. Induk diberi pakan sebanyak $20 \%$ dari bobot induk dengan jenis pakan yang diberikan berupa cacing laut Nereis sp. cumi-cumi Loligo sp., mussel serta pakan buatan (vitalis). Frekuensi pemberian pakan induk yaitu 6 kali per hari dapat dilihat pada Tabel 1.

Menurut Suwoyo et al. (2008), perkembangan gonad dipicu oleh kualitas induk, pakan, dan kondisi lingkungan. Pakan berkualitas sangat berpengaruh pula dalam perkembangan gonad. Beberapa jenis pakan segar seperti daging cumi-cumi, kerang dan cacing sering digunakan dalam proses produksi induk matang gonad. Menurut Wouters et al. (2001), cacing laut berperan penting dalam proses bioreproduksi induk udang maupun ikan, karena cacing laut memiliki kandungan asam lemak tak jenuh 
Iskandar, dkk : Manajemen Pembenihan Udang Vaname Litopenaeus vannamei di PT Central Proteina Prima...

tinggi/ Highly Unsaturated Fatty Acids (HUFA) yang dapat merangsang proses pematangan gonad crustacea dan ikan-ikan laut.

Tabel 1 Jadwal pemberian dan persentase pakan induk

\begin{tabular}{llllllllll}
\hline & \multicolumn{8}{c}{ Jenis Pakan } & \multirow{2}{*}{ Total } \\
\cline { 2 - 10 } & \multicolumn{1}{c}{ Nereis sp. } & \multicolumn{2}{c}{ Loligo sp. } & \multicolumn{2}{c}{ Mussel } & \multicolumn{2}{c}{ Vitalis } & \\
\hline Waktu & 10.30 & 22.30 & 14.00 & 02.00 & 14.00 & 02.00 & 08.00 & 20.00 & \\
\hline$\%$ & $25 \%$ & $25 \%$ & $10 \%$ & $20 \%$ & $5 \%$ & $5 \%$ & $5 \%$ & $5 \%$ & $100 \%$ \\
\hline
\end{tabular}

Pengelolaan Kualitas Air. Pengelolaan air wadah pemeliharaan induk dengan cara pergantian air dan penyifonan wadah induk. Penyifonan dilakukan setiap hari pada pukul 07.00 dan pukul 19.30 untuk membuang sisa pakan dan metabolisme induk.

Pergantian air ditujukan agar kualitas air tetap dalam kondisi yang baik dan induk tidak mengalami stres. Pergantian air dilakukan dengan cara membuka pintu saluran outlet dan membuang air dari volume total kemudian mengisinya kembali dengan air yang baru. Untuk memastikan kualitas air tetap terjaga, selain dengan melihat secara visual kotoran pada bak pemeliharaan, dilakukan pula pengukuran kualitas air seperti suhu, DO, pH, dan salinitas (Tabel 2).

Tabel 2. Kualitas air bak pemijahan induk

\begin{tabular}{llll}
\hline Parameter & Alat & Hasil & SNI (2014) \\
\hline Suhu & Termometer & $27-29^{\circ} \mathrm{C}$ & $28-33{ }^{\circ} \mathrm{C}$ \\
$\mathrm{pH}$ & $\mathrm{pH}$ meter & $7,8-8,0$ & $7,5-8,5$ \\
DO & DO meter & $4-5 \mathrm{mg} \mathrm{L}^{-1}$ & $>4 \mathrm{mg} \mathrm{L}^{-1}$ \\
Salinitas & Refraktometer & $32-33 \mathrm{~g} \mathrm{~L}^{-1}$ & $30-33 \mathrm{~g} \mathrm{~L}^{-1}$ \\
\hline
\end{tabular}

Pencegahan dan Pengobatan Penyakit. Pencegahan penyakit dilakukan dengan menerapkan biosecurity selama kegiatan berlangsung seperti pemakaian sepatu boot, pencelupan kaki pada larutan kaporit (foot bath), serta pembasuh tangan dengan sabun dan alkohol $70 \%$ (hand sanitizer). Setiap dua minggu sekali, air wadah pemeliharaan induk diberikan $\mathrm{KMnO} 4$ dengan dosis $1,5-2 \mathrm{mg} \mathrm{L}^{-1}$ untuk mencegah timbulnya penyakit.

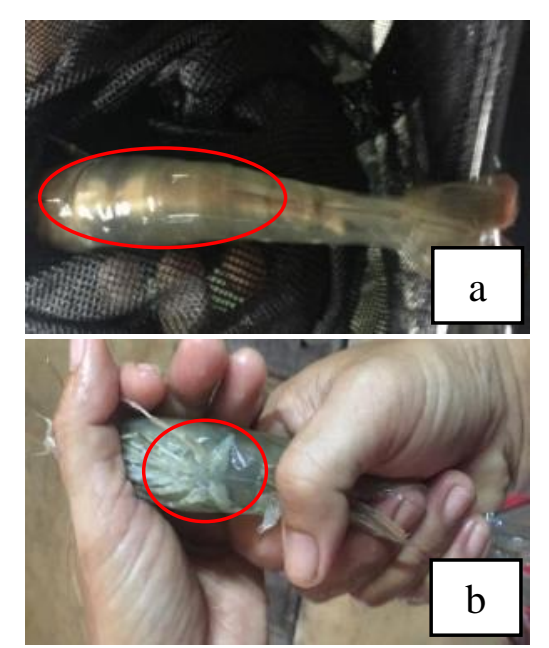

Gambar 1. Pemantauan induk matang gonad: (a) Induk betina matang gonad (TKG IV) dengan ciri berwarna kuning orange dari chepalothorax hingga telson (b) Spermatofor induk jantan

Pemijahan Induk. Perangsangan pemijahan dilakukan terhadap induk betina dengan metode ablasi. Ablasi pada induk betina dilakukan setelah melewati masa karantina yaitu tiga hari setelah dipindahkan induk ke bak maturasi atau ketika induk sudah tidak stres.

Ablasi dilakukan dengan memotong salah satu tangkai mata induk betina ditujukan agar mempercepat kematangan gonad. Subaidah (2006) menjelaskan bahwa dengan dihilangkannya organ $\mathrm{X}$ penghasil hormon penghambat perkembangan gonad atau Gonad Inhibiting Hormone (GIH) yang terletak pada tangkai mata, akan mengakibatkan kerja organ $\mathrm{Y}$ sebagai penghasil hormon yang 
merangsang perkembangan ovarium Gonad Stimulating Hormone (GSH) menjadi tidak terhambat, sehingga akan mempercepat kematangan gonad induk udang betina.

Induk yang akan diablasi ditempatkan di dalam hapa penampungan, selanjutnya dilakukan persiapan alat dan bahan yang digunakan pada saat ablasi. Alat yang digunakan diantaranya camping gas, gunting bedah, serokan, sarung tangan, pengait tangkai mata, dudukan, hapa, gunting, ember, dan gayung, sedangkan bahan digunakan yaitu larutan iodine. Gunting dipanaskan menggunakan camping gas sampai bagian ujung besi gunting berwarna merah nyala. Induk betina dari dalam hapa penampungan ditangkap dengan menggunakan seser selanjutnya induk dicelupkan ke dalam air yang ada di dalam ember. Induk dipegang dengan tenang dan tangkai mata induk dikait dengan alat khusus pengait tangkai mata, selanjutnya tangkai mata digunting sampai putus. Bagian tangkai mata yang telah digunting tersebut dicelupkan ke dalam larutan iodin agar luka bekas ablasi cepat sembuh. Tangkai mata yang dipotong biasanya bagian sebelah kiri, namun jika terdapat tangkai mata sebelah kanan yang telah rusak pemotongan dilakukan pada tangkai mata sebelah kanan agar udang tetap dapat melihat dengan baik. Pada saat udang sedang moulting tidak dilakukan ablasi, karena akan mempengaruhi kondisi induk bahkan dapat mengalami stres.

Pemantauan kematangan gonad dilakukan pada pukul 13.30 dengan cara memindahkan induk betina yang sudah matang gonad ke wadah pemeliharaan induk jantan. Induk betina matang gonad ditandai dengan bagian punggung yang berwarna kuning orange tebal menandakan berisi telur (Gambar 1a), sedangkan pada induk yang tidak matang gonad terlihat lebih transparan. Induk jantan matang gonad, ditandai dengan melekatnya spermatofor yang berwarna puth di bagian pangkal kaki jalan kelima (Gambar 1b). Induk betina matang gonad selanjutnya digabungkan ke dalam wadah pemeliharaan induk jantan agar terjadi proses kawin. Induk yang dipijahkan yaitu induk tingkat kematangan gonad (TKG) 3-4, ciri-ciri dan perbedaan TKG induk udang vaname yang disajikan pada Tabel 3.

Tabel 3. Tingkat kematangan gonad (TKG) induk betina udang vaname (Primavera, 1983)

\begin{tabular}{ll} 
TKG & Ciri dan Perbedaan \\
\hline I & Bagian ovarium masih transparan \\
II & $\begin{array}{l}\text { Adanya garis tipis kekuningan di sepanjang } \\
\text { dorsal }\end{array}$ \\
III & Garis kekuningan mulai menebal dan padat \\
IV & Semakin tebal dan melebarnya ovari \\
\hline
\end{tabular}

Pemeriksaan induk yang sedang kawin dilakukan pada pukul 18.30 selang 5-6 jam setelah penggabungan induk jantan dan betina. Induk betina yang mempunyai gumpalan sperma di bagian thelycum ditangkap dengan menggunakan seser halus, selanjutnya dipindahkan ke dalam wadah pemijahan menggunakan troli yang telah diisi air dan ditambahkan povidone iodine $100 \mu \mathrm{L} \mathrm{L}^{-1}$, sedangkan induk yang tidak kawin dipindahkan ke dalam wadah asal untuk dilakukan pemeliharaan kembali. Fekunditas telur rata-rata induk adalah 4.013.513 butir kg-1

Tabel 4. Hasil pengamatan telur udang vaname

\begin{tabular}{lrrrrrr}
\hline $\begin{array}{l}\text { Kode Wadah } \\
\text { Pemeliharaan }\end{array}$ & $\begin{array}{c}\text { Jml sampling } \\
\text { / 50 mL } \\
\text { (butir) }\end{array}$ & $\begin{array}{c}\text { Jumlah telur } \\
\text { (butir/induk) }\end{array}$ & $\begin{array}{c}\text { Bobot akhir } \\
\text { (g) }\end{array}$ & $\begin{array}{c}\text { Fekunditas } \\
\text { (butir/kg) }\end{array}$ & FR (\%) & HR (\%) \\
\hline 11A & 66 & 356.400 & 88,8 & 4.013 .513 & 86,36 & 85,2 \\
11B & 71 & 383.400 & 88,4 & 4.337 .105 & 85,9 & 81,8 \\
& & 369.900 & & 4.175 .309 & 86,13 & 83,5 \\
\hline
\end{tabular}

Pemanenan Telur. Berdasarkan hasil perhitungan (Tabel 4), diperoleh jumlah telur induk vaname sebanyak 356.400 sampai dengan 383.400 butir induk $^{-1}$. atau rata-rata 369.900 butir induk $^{-1}$. Sedangkan persentase jumlah telur yang dibuahi (FR) berkisar antara 85,9\% sampai dengan 86,36\% atau rata-rata 86,13 . 
Telur dipanen dengan cara membuka outlet wadah lalu disaring menggunakan saringan ukuran 150 mesh, telur yang tersisa di dalam wadah dibilas dengan air secara perlahan sampai telur habis. Telur hasil panen dibersihkan dengan air yang telah ditambahkan larutan povidone iodine $100 \mu \mathrm{L} \mathrm{L}^{-1}$ dan kotoran disaring dengan saringan ukuran 56 mesh, kemudian telur diendapkan selama 1-2 menit. Telur yang telah dicuci kemudian dipindahkan ke dalam wadah penetasan telur.

Penetasan Telur. Penebaran telur ke dalam wadah penetasan dilakukan setelah proses panen telur dan pencucian telur. Proses penetasan telur berkisar antara 11-12 jam. Selama proses inkubasi, telur diaduk dengan pengaduk otomatis dan pengaduk manual. Pengadukan manual dilakukan ketika kinerja dari pengaduk otomatis kurang maksimal, jika telur tidak diaduk kemungkinan akan telur akan membusuk, pengadukan dilakukan di kolom air tanpa menyentuh dasar wadah agar telur tidak rusak. Proses pengadukan manual membutuhkan waktu kurang lebih 10 detik setiap wadah. Derajat penetasan telur (HR\%) yang dihasilkan berkisar antara $81,8 \%$ sampai dengan $85,2 \%$ atau rata-rata $85,3 \%$.

Pemanenan Naupli dan Pemeliharaannya. Pemanenan naupli stadia 1-2 dilakukan dengan menggunakan seser 150 mesh. Naupli kemudian direndam di dalam larutan povidone iodine $50 \mu \mathrm{L} \mathrm{L}^{-1}$ selama 10 detik dan dipindahkan ke dalam wadah pemeliharaan. Agar kualitas naupli tetap terjaga, dilakukan rinsing yang bertujuan untuk menghilangkan kotoran dan naupli menjadi bersih. Rinsing dilakukan sekitar 8 jam dengan menggunakan air mengalir secara kontinyu melewati pipa 1,5 inci yang telah diberi lubang-lubang kecil untuk pengeluaran air bersih.

Pemanenan naupli stadia 4-5 dilakukan dengan cara melepaskan aerasi dan filter yang terdapat di dalam wadah pemeliharaan, Naupi diseser menggunakan seser 150 mesh dan direndam di dalam larutan povidone iodine $50 \mu \mathrm{L} \mathrm{L}^{-1}$, selanjutnya dimasukkan ke dalam kantong plastik kemas yang sudah diberi kode modul dan nomor wadah pemeliharaan tahap berikutnya. Jumlah naupli untuk setiap kantong plastik kemas sebanyak 70.000-87.500 ekor, berisi air 8-10 L, dengan DO minimal 7 mg L-1. Perbandingan oksigen dan air di dalam kantong plastik kemas adalah 1:1. Setelah proses pengemasan selesai, naupli dipindahkan ke dalam hatchery untuk dipelihara sampai ukuran panen.

Persiapan Wadah Pemeliharaan Larva. Persiapan wadah pemeliharaan larva dilakukan dengan membersihkan dan melakukan sterilisasi ruangan, lantai, peralatan, dan wadah pemeliharaan. Sterilisasi dilakukan dengan pencucian wadah menggunakan detergen $10 \mathrm{~g} \mathrm{~L}^{-1}$ kemudian dibilas menggunakan air bersih yang ditambahkan larutan povidone iodine $1.000 \mu \mathrm{L} \mathrm{L}^{-1}$, setelah itu dilakukan penyiraman dengan kaporit $\mathrm{Ca}(\mathrm{ClO})_{2}$ sebanyak $1.000 \mathrm{mg} \mathrm{L}^{-1}$ kemudian wadah dikeringkan. Menurut Said (2007), kaporit digunakan sebagai bahan desinfektan dalam pengolahan limbah cair karena kandungan klor pada kaporit terutama $\mathrm{HOCl}$ umumnya sangat efektif untuk inaktivasi patogen dan bakteri indikator.

Peralatan dicuci menggunakan detergen $10 \mathrm{~g} \mathrm{~L}^{-1}$, kemudian direndam formalin $\mathrm{CH}_{2} \mathrm{O} 1.000 \mu \mathrm{L}$ $\mathrm{L}^{-1}$. Tahapan berikutnya adalah instalasi wadah pemeliharaan berupa pemasangan filter bag pada pipa inlet, filter outlet, termometer, dan instalasi aerasi (jarak antar titik 40-45 cm dan jarak batu aerasi ke dasar wadah sekitar $5 \mathrm{~cm}$ ). Wadah pemeliharaan selanjutnya diisi air laut dan dilakukan penambahan virkon akuatik sebagai desinfektan sebanyak $1,2 \mathrm{mg} \mathrm{L}^{-1}$ kemudian diamkan selama 24 jam, setelah itu dilakukan pemberian EDTA $\mathrm{C}_{10} \mathrm{H}_{16} \mathrm{~N}_{2} \mathrm{O}_{8}$ sebanyak 10-20 mg L ${ }^{-1}$. Aerasi dihidupkan agar bahan yang ditambahkan homogen dan air pemeliharaan siap digunakan.

Penebaran Naupli. Naupli ditebar ke dalam wadah pemeliharan dengan kepadatan rata-rata yaitu 6.000.000 ekor untuk wadah bervolume 35.000-40.000 L dan 8.000.000 ekor untuk wadah bervolume 45.000-50.000 $\mathrm{L}$ atau dengan padat tebar 130 ekor $\mathrm{L}^{-1}$.

Pemberian Pakan. Pakan yang diberikan untuk naupli adalah pakan buatan dan pakan alami. Pemberian pakan alami berupa alga hijau (Tetraselmis sp.) dan alga diatom (Thalaasiosira sp.) sebanyak 2 kali pemberian, yaitu pukul 08.00 dan 15.00, mulai awal pemeliharaan sampai stadia PL 1. Pemberian artemia (Artemia sp.) sebanyak 6 kali yaitu pukul 08.00, 11.00, 15.00, 20.00, 23.00, dan 03.00 yang diberikan dari stadia PL I sampai dengan periode panen. Pakan buatan diberikan sesuai dengan stadia larva (Tabel 5). 
Tabel 5. Jadwal pemberian larva udang vaname

\begin{tabular}{|c|c|c|c|c|c|c|c|c|c|c|c|c|c|c|c|c|}
\hline \multirow{3}{*}{ Pakan } & \multicolumn{16}{|c|}{ Stadia } \\
\hline & \multicolumn{6}{|c|}{ Zoea } & & & & & & & & & & \\
\hline & $\mathrm{N}$ & 1 & $1-2$ & 2 & 3 & 1 & 2 & 3 & 1 & 2 & 3 & 4 & 5 & 6 & 7 & 8 \\
\hline $\begin{array}{l}\text { Endogenous feeding } \\
\text { Alga }\end{array}$ & & & & & & & & & & & & & & & & \\
\hline Pakan Buatan & & & & & & & & & & & & & & & & \\
\hline Artemia sp. & & & & & & & & & & & & & & & & \\
\hline
\end{tabular}

Teknis pemberian pakan alami alga dilakukan dengan cara mengalirkan alga umur 2 hari kultur (DOC) dari wadah kultur massal ke dalam wadah pemeliharaan naupli melalui saluran dengan menggunakan pompa. Artemia diberikan ke dalam wadah pemeliharaan naupli secara merata dengan menggunakan ember dan gayung. Pada naupli stadia awal sampai dengan stadia mysis, pakan buatan diberikan 8 kali dalam sehari, yaitu pada pukul 07.00, 10.00, 13.00, 15.00, 19.00, 22.00, 01.00 dan 03.00. Untuk stadia PL 1 sampai ukuran panen, pakan buatan diberikan sebanyak 6 kali dalam sehari, yaitu pukul 07.00, 10.00, 14.00, 19.00, 22.00 dan 02.00. Pakan buatan diberikan ke naupli dengan cara diencerkan air menggunakan saringan pakan agar pakan tidak menggumpal.

Pengelolaan Kualitas Air. Pengelolaan kualitas air yang dilakukan adalah dengan pemberian probiotik dan molasis, pemberian EDTA, dolomit, pengukuran parameter kualitas air, serta pergantian air sebanyak 5-20\% dari volume air wadah pemeliharaan, yang dilakukan mulai stadia mysis sampai dengan stadia post larva.

Probiotik adalah istilah yang digunakan pada mikroorganisme hidup yang berupa bakteri 'baik' yang dapat memberikan efek baik atau kesehatan pada organisme inangnya. Probiotik yang diberikan pada pemeliharaan larva yaitu pro-4 (Bacillus sp.) dengan dosis berbeda diberikan pada setiap stadia. Dosis pro-4 untuk stadia zoea sebanyak $6 \mu \mathrm{L} \mathrm{L}^{-1}$, stadia mysis $10 \mu \mathrm{L} \mathrm{L}^{-1}$, dan stadia PL sebanyak $20 \mu \mathrm{L}$ $\mathrm{L}^{-1}$.

Pemberian molasis bertujuan sebagai makanan bagi bakteri probiotik. Sama halnya seperti probiotik, dosis molasis yang diberikan untuk setiap stadia juga berbeda, untuk stadia zoea sebanyak 6 $\mu \mathrm{L} \mathrm{L}{ }^{-1}$, stadia mysis $8 \mu \mathrm{L} \mathrm{L}^{-1}$, dan stadia PL sebanyak $10 \mu \mathrm{L} \mathrm{L}^{-1}$. Pemberian probiotik dan molasis dilakukan setiap hari sekitar pukul 08.00.

Pemberian EDTA $\mathrm{C}_{10} \mathrm{H}_{16} \mathrm{~N}_{2} \mathrm{O}_{8}$ berfungsi untuk mengikat kandungan logam berat seperti besi dan tembaga (Aziz T et al. 2015). EDTA diencerkan dahulu dengan air, selanjutnya ditebar ke dalam air wadah pemeliharaan dengan dosis 10-20 $\mathrm{mg} \mathrm{L}^{-1}$. Pemberian EDTA dilakukan satu hari sebelum naupli ditebar dan diberikan pada pagi atau malam hari (setiap perpindahan stadia dimulai dari zoea 1-2).

Pemberian dolomit $\mathrm{CaMg}\left(\mathrm{CO}_{3}\right)_{2}$ berfungsi sebagai buffer (alkalinitas) karena mengikat $\mathrm{CO}_{2}$ menjadi bentuk $\mathrm{HCO}_{3}{ }^{2-}$ sehingga dapat menekan konsentrasi amonia (Purwakusuma 2007). Dosis dolomit yang diberikan yaitu $100 \mathrm{mg} \mathrm{L}^{-1}$. Dolomit mulai diberikan hanya untuk stadia mysis 2 dan PL 2. Pemberian dolomit dilakukan sore hari sekitar pukul 15.00. Pengukuran parameter kualitas air dilakukan untuk mengontrol keadaan air pada wadah pemeliharaan. Hasil pengukuran yang diperoleh adalah suhu $30-33{ }^{\circ} \mathrm{C}$, $\mathrm{pH}$ 8,0-8,3, DO 5-10 $\mathrm{mg} \mathrm{L}^{-1}$, dan salinitas 31-33 $\mathrm{g} \mathrm{L}^{-1}$.

Pemantauan Populasi. Pemantauan populasi dilakukan dengan cara mengambil sampel benur menggunakan gelas beaker $500 \mathrm{~mL}$ yang selanjutnya hasil sampling dituangkan ke dalam gayung pakan untuk dihitung. Pemantauan populasi dijadikan sebagai acuan estimasi jumlah udang dalam wadah pemeliharaan dan sebagai acuan jumlah pemberian pakan pada pemeliharaan benur udang vaname. Estimasi populasi didapat dengan cara perhitungan sebagai berikut:

$$
\text { Populasi }=\frac{\text { Jumlah sampel benur }}{\text { Volume air wadah sampel }} \times \frac{\text { Volume air wadah }}{\text { pemeliharaan }}
$$

Pemanenan Benur. Pemanenan benur dilakukan pada stadia PL 4 dan stadia PL 7-10. Syarat agar benur bisa dipanen adalah lolos uji formalin stress test, salinity stress test, dan bebas penyakit yang dibuktikan dengan hasil uji PCR, dan bebas dari luminescent bacteria. Hasil uji PCR harus bebas dari 
Iskandar, dkk : Manajemen Pembenihan Udang Vaname Litopenaeus vannamei di PT Central Proteina Prima...

Systemic Ectodermal and Mesodermal Baculo Virus (SEMBV), Infectious Hypodermal and Hematopoietic Necrosis (IHHNV), Taura Syndrome Virus (TSV), dan Infectious Myonecrosis Virus (IMNV) yang biasa menyerang udang vaname.

Data panen benur untuk satu siklus produksi sebanyak 54.451.910 ekor dengan rata-rata Survival rate (SR) sebesar $75 \%$ (Tabel 6). Pemanenan dilakukan dengan cara menyurutkan air di dalam wadah pemeliharaan sebanyak $40 \%$ kemudian jaring panen dipasang. Saluran outlet wadah dibuka, dan benur yang terbawa aliran air ditampung menggunakan jaring panen berukuran 150 mesh. Benur yang terkumpul di dalam jaring panen diambil menggunakan seser dan dipindahkan ke dalam ember yang telah diisi air. Benur selanjutnya diangkut ke wadah penampungan sementara yang telah diatur suhunya pada kisaran $28^{\circ} \mathrm{C}$.

Tabel 6. Data hasil panen benur

\begin{tabular}{cccc}
\hline Bak & Tebar (ekor) & Panen (ekor) & $S R(\%)$ \\
\hline D 49 & 6.390 .000 & 5.945 .400 & 93,0 \\
D 50 & 6.480000 & 3.654 .085 & 56,3 \\
D 51 & 6.570000 & 4.098205 & 62,3 \\
D 52 & 6.570 .000 & 6.026 .160 & 91,7 \\
D 53 & 6.390 .000 & 5.040 .000 & 78,8 \\
D 54 & 6.300 .000 & 5.303 .000 & 84,1 \\
D 55 & 8.730 .000 & 6.474 .960 & 74,1 \\
D 59 & 6030.000 & 6.029 .300 & 99,9 \\
D 60 & 6.300 .000 & 3.505 .920 & 55,6 \\
D 61 & 6.480 .000 & 5.345 .100 & 82,4 \\
D 63 & 6.390 .000 & 3.029 .780 & 47,4 \\
\hline Rata-rata & 6.602 .727 & 4.950 .173 & 75,0 \\
\hline Total & 72.630 .000 & 54.451 .910 & \\
\hline
\end{tabular}

Proses pengemasan dilakukan oleh beberapa orang yang bertugas sebagai scooper yaitu orang yang melakukan scooping dengan scoope yang ukurannya berbeda sesuai dengan kepadatan yang diinginkan dalam satu kantong plastik. Kepadatan scoope untuk benur PL 4 yaitu 4.000-7.000 ekor benur dan untuk PL diatas 7 yaitu 1.150-2.500 ekor benur.

Proses pengemasan diawali dengan memasukkan air sebanyak $5 \mathrm{~L}$ ke dalam kantong plastik kemas ukuran $35 \mathrm{~cm}$ x $150 \mathrm{~cm}$, karbon aktif sebanyak $3 \mathrm{~g}$, selanjutnya benur dimasukkan ke dalam kantong tersebut. Perbandingan antara oksigen dan air di dalam kantong pengemasan adalah 1:1. Ujung kantok plastik kemas dibentuk menyerupai konde dan diikat menggunakan karet gelang. Kantong plastik berisi benur kemudian dimasukkan ke dalam box styrofoam, yang telah diberi batu es dan siap untuk dikirim ke lokasi konsumen.

Pengiriman Benur. Pengiriman benur dilakukan setelah proses pengemasan selesai, dengan menggunakan pengangkutan sistem tertutup. Alat transportasi yang digunakan untuk pengangkutan disesuaikan dengan jumlah benur yang akan dikirim dan jarak tempuh. Benur produksi PT CPP Kalianda dipasarkan ke wilayah Situbondo, Banten, Pangandaran, Rembang, Bangka, dan Lampung.

\section{KESIMPULAN}

Kegiatan pembenihan udang vaname meliputi persiapan wadah, pemeliharaan induk, pemijahan induk, pemeliharaan dan penetasan telur, pemeliharaan naupli, pemeliharaan benur, pengelolaan kualitas air, serta pemanenan dan pengiriman benur. Hasil pengamatan didapatkan jumlah telur dengan rata-rata yaitu 369.900 butir induk $^{-1}$, Fertilitation Rate (FR) sebesar 86,13\%, dan Hatching Rate (HR) sebesar 83,5\%. Tingkat kelangsungan hidup (SR) rata-rata yang dihasilkan adalah $75 \%$. 


\section{DAFTAR PUSTAKA}

[FAO] Food and Agricultural Organization. 2014. The State of World Fisheries and Aquaculture (SOFIA). http://www.fao.org/3/a-i3720e.pdf. Diakses tanggal 18 September 2019.

Ahmadi H, Iskandar N, Kurniawati. 2012. Pemberian Probiotik dalam Pakan Terhadap Pertumbuhan Lele Sangkuriang (Clarias graprienus) pada Pendederan II, 3(4): 99-107.

Aziz T, Amalia Rizky P, Vishe Devah. 2005. Removal Logam Berat dari Tanah Terkontaminasi dengan Menggunakan Chealating Agent (EDTA). Jurnal Teknik Kimia, 2(21).

Briggs M, Smith S F, Subasinghe R, Philips M. 2004. Introduction and Movement of Penaeus vannamei and Penaeus stylirostris in Asia and The Pacific. RAP Publication 2004/10: 136-140.

Keputusan Menteri Kelautan dan Perikanan Republik Indonesia Nomor KEP.45/MEN/2011 tentang Estimasi Potensi Sumber daya Ikan di Wilayah Pengelolaan Perikanan Negara Republik Indonesia.

Primavera J H. 1983. Review of maturation and reproduction in closed thelycum penaeids. Di dalam: Proceeding of the First International Conference on the Culture of Penaeid Prawn/Shrimps. Aquaculture Department Southeast ASEAN Fisheries Development Centre. Iloilo. Philippines. hlm 47-64.

Purba O S. 2008. Pengembangan Medium untuk Peningkatan Produktivitas Kultur Batch Diatom Laut Thalassiosira sp. . [Tesis]. Bandung (ID): Institut Teknologi Bandung.

Purwakusuma. 2007. Daphnia sp. Media Informasi Ikan Hias. Jakarta.

Sibbald R, Kevin W, Elizabeth A. 2011. Increased bacterial burden and infection: NERDS and STONES. Wound Repair Regen. 31(1): 34-42.

Subaidah S, Pramudjo, Asdari M, Imam N, Sugestya, Nurul D, Cahyaningsih S. 2006. Pembenihan Udang Vaname (Litopenaeus vannamei). Situbondo (ID): Balai Budidaya Air Payau Situbondo.

Suwoyo D, Soleh M, Gunarso A. 2008. Peningkatan Produktivitas Induk Udang Windu (Penaeus monodon Fab.) dengan Menggunakan Bubuk Paprika. Media Budidaya Air Payau Perekayasaan. (7) : $1-11$.

Wouters, R P, Lavens J, Nieto and Sorgeloos P, 2001. Penaeid Shrimp Broodstock Nutrition: an Updated Review on Research and Development. Aquaculture, 202: 1-21. 